\title{
Recasting Urban Identities: The Case of Madrid 1977- 1997
}

(C) Malcolm Alan Compitello

The University of Arizona

\section{E-mail -compitel@email.arizona.edu}

The title of this paper suggests a series of connections that merit comment at the outset. It will discuss the transformations of a particular urban place in Spain, Madrid, during a specific period in time, as well as the way in which culture produced there responds to these transformations. The use of the word "recasting" in the title suggests some powerful processes directing this transformation of identity, particularly urban identity [1]. There is no term in the critical archive that has been more used in discussing recent political, social, and cultural events in Spain than identity [2]. By qualifying identity with urban, I am suggesting an approach somewhat different than the ones used by the majority of those who have examined Spain through the lenses of regional, national and gender-based identity issues. Hopefully, the body of this paper will illuminate how the concept of urban identities works with specific reference to Spain's capital city, Madrid, at a crucial time in its urban evolution.

The remarks that follow are divided into three sections. The first spells out the theoretical frame for approaching the question of identity from an urban perspective. The second comments on how the urban process plays out in Madrid during the time frame indicated by this paper. The third examines some recent films about Madrid.

\section{The Urban Experience}

David Harvey's The Urban Experience provides the inspiration for the title of this section. More than any other theorist, Harvey is responsible for correcting a shortcoming in materialist thought, where emphasis on the historical, temporal domain leaves out the dimension of space in all of its complexity. Harvey's extensive work should be read, first and foremost, as an attempt to fine tune Marxist metatheory that replaces historical materialism with historicalgeographical materialism, thus emphasizing the importance of spatial issues. Starting from this perspective, Harvey has produced a distinguished corpus of work that examines a number of issues all emphasizing the interconnectedness of matters of space and place as well as capital.

Harvey builds on the work of the French urbanist Henri Lefebvre who, in The Production of Space, asserts that capital reproduces itself through the manner in which it appropriates space, especially urban space. The built environment of urban areas, Harvey states, is the second nature of capital. The conjoining of capital and space allows Harvey to articulate the two basic tenets of his work: 
the urbanization of capital and the urbanization of consciousness. With the idea of the urbanization of capital Harvey suggests an inexorable link between capitalism and cities. Capital is an eminently urban form. Its evolution over the last two and a half centuries is inexorably bound up in the way it has been able to maintain and transform itself through the acts of creative destruction that have a decisive impact on the built environment of cities and on the people who inhabit them. This process creates the close relationships among money, space, time, and the city. These relationships are what, in turn, form urbanized consciousness, individual and group responses to life in a city built in the image of capital. Harvey identifies five primary areas of consciousness formation: individualism, class, community, the state, and the family. Their dynamic interplay forms urban consciousness. The task for a historical-geographical materialist interpretation of the urban process, according to Harvey, is to:

Examine how the ways of seeing, thinking and acting produced through the interrelations between individualism, class, community, state and family affect the paths and qualities of capitalist urbanization that in turn feed back to alter our perceptions and our actions. (The Urban Experience, 231)

Moreover, it is in the urban context that, to again quote Harvey,

firmer connections between the rules of capital accumulation and the ferment of social, political and cultural forms can be identified. In so doing I reiterate that the urban is not a thing, but a process and the process is a particular example of capital accumulation in real space and time. (The Urban Experience, 247)

Capital shapes consciousness, and consciousness is both formative of and formed by cultural and social forms. This process-based view represents an important corrective to analyses that focus on products. For example, it underscores the shortsightedness of approaches to the city and its problems that assume that a rearrangement of the built environment in and of itself solves anything. Building is only an intermediary step in the continuing process of answering the basic question about social justice and the city: "whose city is this?"

The dynamic relationship between space and place is one particularly important ramification of these relationships. As capital extends itself more and more through space as a way to confront changing economic realities, it increases the uneven development of place. I concur with Harvey's assertion that instead of concerning ourselves with globalization and its effects-capital has been transnational and globally oriented since its inception-emphasis should be placed on the disastrous effects that this uneven development and expansion of space has had on place, on each of the individual cities or urban regions touched by it. This becomes increasingly important from the mid 1970s on when a series of economic and financial changes heated up capitalist competition and made it more frenetic and destructive. Harvey and others have 
called this phase in evolution of capital flexible accumulation. Capital is no longer tied to place and space in the same way it was in earlier periods. Cities and urban regions now must compete to attract capital or else perish. One of the ways they attempt to do this is through increasingly expensive redevelopment projects aimed at recapturing high-end residents and corporate command and control centers. In addition, since industry long ago fled cities (thus breaking the relationship between life and work), cities now often base their competition on consumption rather than production. Shopping malls and museums that have become not only repositories of culture but sites for upscale gift shops and restaurants have become more and more prevalentthirty were built in Spain in the 1980s and 1990s. The city as playground or cultural shopping mall also plays on a transient sense of history, which is what Harvey and others call the heritage industry. Many who have studied the extension of these processes around the world have followed Harvey's lead and talked about the process of Selling Place. Cities fight for global capital through the construction of space and repeat the processes of creative destruction and uneven development in places that characterize the paranoia of capital. They also become the sites of an increasingly pernicious process of exclusion etching sharply on the urban consciousness the ever-wider difference between the haves and the have-nots. Paradoxically, place becomes even more important as well as the basic point of hegemonic assertion of the role of capital, the promotion of the city as growth machine. It also can be where capital can be contested.

Resistance, while not futile, can be problematic. In can unleash waves of militant particularism that can adversely affect any attempt to contest capital. Secondly, money sometimes makes individuals work against the interest of their own class and react to the urbanization of capital and the urbanization of consciousness in contradictory ways that stem from how they react to the pull of money and capital on the various constituencies that form urbanized consciousness.

\section{MADRID, CAPITAL}

The project of reconstructing a new Spain out of the ruins of the Francoist dictatorship was, to be sure, one of recasting identity. On one level there was a conscious effort to forget the recent past, a political pact to which all the major political parties subscribed, some of which were only legalized several years after Franco's death. The PSOE's (Partido Socialista Obrero Español or Spanish Workers' Socialist Party) rise to political hegemony was in great part predicated on fostering a new version of the old Francoist tourist slogan, "Spain is different." This time the "different" Spain being promoted and forged was a country that sought to align its image with that of its future partners in the European Community. 
Culture played an important part in this process. For example, Martínez Bouza, commenting on the fashion industry, said that the Socialist government wanted to "generar ídolos y vender España" (49). It was certainly true that the spate of Spaniards who rose to prominence around the world in disciplines such as graphic and industrial design, film, fashion, and architecture aided this process of image creation.

These fields, while diverse, share two elements that help us draw these processes of image transformation into sharper focus. In the first place, they are all eminently urban phenomena and it is not surprising that the efforts to recast Spain's identity were, above all, the product of its rapidly evolving cities. In the second place, they are all the kind of applied arts that are most directly related to the circulation of capital, especially the latest kinds of capitalist accumulation where consumption plays as crucial a role as production and, therefore, where image production and the commodification of culture become inexorably bound. Cities, culture, capital would be the formula for recasting urban identities. Capital would serve as that powerful agent for image formation that I mentioned earlier.

To provide a brief illustration, let me explain how this process worked in relationship to the built environment in Madrid. I want to pay particular attention to the role of urban planning in the creation of the city during this period since it was the ground zero for battles over what the shape of the city was to be.

When the Socialists took office in Madrid in 1979, they were faced with a number of challenges, not the least of which was rationalizing the planning process and attempting to stop Madrid's urban blight much of which resulted from uncontrolled speculative urbanism of the last decades of the dictatorship. The revision of the Plan General Urbano de Madrid was undertaken in this climate by the new socialist city administration and would be joined, just as the plan was in its final phases of preparation, by planning at the regional level once the charter for Madrid's comunidad autónoma-the last of the comunidades approved-went into effect in 1983. [3]

The 1985 plan represented a change in the approach to both the planning process and to the built environment itself. From the mid-1970s on, Madrid, like other Spanish cities, had begun to lose population and suffer the effects of the economic crises of the mid and late 1970s, from which Spain had not yet recovered at the time the plan was being prepared. If Harvey and others, in talking about the dynamics of the ways cities changed around the world from the mid 1970s on, evoke the shift from modernist urban planning to a more chaotic project driven by urban design, the 1985 plan is clearly in the first camp. [4] It was a plan based on bottom up decision-making. Its goal was social justice and making the city inhabitable for all segments of the population. Preserving the urban core from decay, guaranteeing adequate housing and assuring the government's role in that process, and reformulating urban access 
by emphasizing public and limiting private transportation were all prominent features of this proposed transformation. Perhaps the first of the plan's objectives says it best; make all parts of the city accessible to all citizens. In fact it was exactly the kind of political planning process one would expect from a political party that, at the time the plan was written, actively promoted its position of defending social justice. It is significant in this regard that the Avance del Plan, published in 1982, is titled Recuperar Madrid.

Planning was to be used politically to assure the rights to the city for all. In this way the Plan General of 1985 should be seen as an attempt to stop the processes of flexible accumulation, which by that time had begun to overtake planning around the world, and to remake Madrid according to another model.

Given the very drastic nature of many of the problems that Madrid faced, a decision was made to privilege urban projects over larger planning issues. Ensuing from this approach was an emphasis on the city center and a relative lack of attention to the idea of Madrid as an urban region. A little historical perspective here is useful. It was really only after the transfer of power to the autonomous regions that the idea of regional planning was resurrected-an important turn since most of the growth in Spanish urban regions since the 1980s was not in the central municipality but in the surrounding urban region. [5]

The urgency of dealing with specific issues-of solving crucial problems as quickly as possible, of altering the urban space in the city center for the benefit of the residents of each barrio, and of putting a stop to the speculative urbanism that was destroying the city center-was well intentioned. It did much to transform the city and improve the lives of those who lived there.

Nevertheless, it opened the door for later city governments that did not share the socialist planners' desire to use planning as a tool for achieving social justice, or to use design over planning to effect a different kind of change in the city and the urban region-a change one predicated not on social justice but on urban boosterism and selling place.

Moreover, the "project fix" tended to fix in place the role of big name architects who were hired by government agencies and the private sector to take on the projects, lending validity to the results-those wonderful buildings to which the government and the private sector could point as manifestations of the fundamental changes in the city-yet in some ways compromising the process. I am skeptical of a completely morphological approach to solving Madrid's problems, one that views the produced built environment rather than the process as the ultimate measure of the value of planning. Nevertheless, part of the end result was an emphasis of slick outward appearances that did not always coincide with the planners' diagnostic of the city's problems or the solutions they proposed. 
Even before the 1985 plan could be finished, it was being out-flanked by the major thrust of a new centrist agenda for the PSOE. The planners on the left spoke the language of social justice while those controlling the purse strings and the national agenda for the party increasingly spoke the language of flexible accumulation. The Plan's critics, and they were legion, accused the planners of advancing an ideological agenda. Of course they did, and of course every planning agenda is to a greater or lesser degree ideological. The real problem was capital. Funds were not available to support the kinds of investments (in public transportation, for example) on which the plan hinged. Moreover, the private sector was reticent to embrace a plan for housing that preached social justice instead of the miracle of the market place-the gospel according to Thatcher and Reagan.

The internal contradictions of planning that characterized the PSOE and its planning processes became more prevalent once the political process at the municipal and regional levels began to play out against the evolving desires of the electorate. The PSOE, which won the municipal elections in 1979 held on to the city government in the 1983 municipal elections but, while it won the most seats in the 1987 election, it lost control of the city council to a center-right coalition. In 1991 and in subsequent elections, the PP (Partido Popular or People's Party) won the majority of the seats on the city council.

The first elections for the regional government of Madrid saw the PSOE also come out on top, a position it maintained either independently or in a coalition until 1995, when the PP won an absolute majority.

As the political climate changed so did the conception of planning. The myriad of subsequent planning documents at the regional and city levels are decidedly different than the first socialist city plan for Madrid of 1985.

The consumer, not the producer or the resident, has become the prime mover of the planning, aligning this plan and the Madrid that issues from it with the serial versions of cities of consumption that crop up all over the world. Nothing illustrates this agenda better than the reorientation of the treatment of transportation and parking issues. The new emphasis is again on cars and is endemic of a vision of the city being tied to affluent northern and eastern suburbs. These areas continue to expand rapidly and their residents are less interested in public transportation.

The 1985 plan represented perhaps one of the last great attempts at rational modernist urban planning with an emphasis on social justice and on protecting the rights of all of the residents. Its collapse under the internal pressures of socialism's failure to confront more flexible, consumption-based visions of the urban first and of those visions' rapid expansion under less-enlightened governments, is sad. The resistance to predatory capital was no longer a 
concern of planning and of governmental agencies. It was, nonetheless, a battle played out in a number of arenas, one of which was culture.

\section{Madrid as Cinematic City}

The processes of urban transformation attempted by the planners differed in one fundamental way from planning under the dictatorship. It was and is open to public scrutiny and subject to the will of the electorate in the political process. The debates over urban issues were played out in the pages of Madrid's daily press and other media venues. In this way, the second nature of capital-its effect on the built environment-had an effect on the second human nature formed in response to the process of the urbanization of consciousness. The urban process and the transformations it wrought on the city were everywhere present. They were certainly part of the urbanized consciousness of the cultural creators during the 1980s and 1990s (to judge from the intense interest that urban issues exerted on the culture created in Madrid during this period).

If architecture represents the insertion of capital in space, then it is in film that this built environment finds a particularly important visual representation. Film coalesces artistic visions and shapes a snap shot of life in the city against the backdrop of the built environment. A movie is the product of urbanized consciousness, the end result of the process through which a creator goes in thinking about issues of life in the city and how to portray that image on the screen. In turn, these visions of the city shape subsequent ones, cultural, social, economic, and political. At the same time, a film situates a particular vision of the city on a sliding scale between criticism of hegemonic urban practices and accommodation of a less contestatory consumerist culture, which increasingly characterizes life in Madrid.

I will attempt to draw some conclusions about Madrid as cinematic city-a title that I borrow from the collection of essays edited by David B. Clarke [6]-by examining two movies in particular from an interesting body of films that appeared in the 1990s: Alejandro Amenábar's Abre los ojos (1997) [7] and Fernando León de Aranoa's Barrio (1998) [8]. I will also make reference to Alex de la Iglesia's El día de la bestia (1995), a film about which I have written elsewhere. This selection is from a spate of recent films that foreground life in Madrid and some of the classic post-cambio films set there, as well as the vast majority of the fascinating body of work of Pedro Almodóvar.

When asked about the influence of architecture in his films, Alejando Amenábar made the following comment about his second film, Abre los ojos. "En la segunda película en que creaba microuniversos en cada secuencia, siempre tenía que buscar la arquitectura adecuada." [9] Amenábar adds that he prefers to work in spaces and places with which he is familiar, namely the city of Madrid, and give the city certain twists that present it in an interesting and different light-one which forces people to see the familiar in a new way. In other 
words, Amenábar wants to open spectators' eyes and enable them to see what otherwise might remain invisible.

Filmic representations of a city can be more or less synthetic but may employ certain visual anchors that locate the city in the flow of urban space and the specificity of place. The first sequences of $\underline{A b r e}$ los ojos demonstrate this. The first takes place in the swanky duplex of the film's twenty-six year old protagonist, César. Second, César drives his car out onto the street as he becomes increasingly concerned about the fact that it is 10:00 A.M. and there is nobody around. Third, César comes to a large street and begins to run down it in a panic about the fact that it is time for the morning rush hour and he appears to be the only one in the city.

These three sequences invoke the created space of the modern Spanish urban environment and the specifics of place reference. The first sequence could be a location shot, or a studio set, but it evokes images of money and class. The second sequence may or may not be shot in Madrid, but points to a trendy upper class neighborhood congruent with the previous sequence. The third sequence, however, is rooted in place. The street onto which César turns is the last section of the Gran Vía as it descends to the Plaza de España. Smack in the middle of the frame is the Torre de Madrid looming up from its place in the Plaza de España which itself establishes the boundary between the Gran Vía and the Calle Princesa.

This third sequence is crucial for the development of the movie's plot. It allows the spectator to intimate the relationships between differing versions of reality and to ultimately get at the relationships between dream and reality that forms the film's thematic core. It also permits the viewer to begin to construct a variety of visual and literary intertexts, including Calderón's La vida es sueño, Hitchcock's Vertigo, and the myriad of 1990s films about virtual realities. But we cannot discard the built environment of Madrid as the contextual anchor for the film. By making César see things through a new light-the buildings without the people-Amenábar privileges the built environment and brings it front and center. That he does the same thing at the end of the film, when the dream is played out in the film's epilogue, underscores the urban subtext to this otherwise flashy international tale of dreams and virtual reality.

Nothing, of course, would invoke in a Madrileño the sense of being in a dream more than arriving at the Gran Vía at ten in the morning and finding it vacant. Moreover, the shot of César disappearing down toward the Plaza de España with the Torre de Madrid overflowing the frame evokes an important transition in the urban process of Madrid. The buildings along the Gran Vía are in great part the product of the first period in modern Spanish history (1910-1936), when debates about the nature of what it meant to be modern, significant planning, and urban reconstruction co-existed. The buildings in the Plaza de España and up Princesa are mostly the work of urban development under the 
dictatorship. Capitalist interests unite them, however, and, in fact, the same architects designed many of them.

Let's now fast-forward to the final sequences of the film, which also transpire in relationship to Madrid's built environment. César and his psychiatrist, Antonio, stand outside the tall building they have just exited and outside of which Antonio seemingly died protecting César from the bullets of police officers who are pursuing him for having shot one of their colleagues. César has just discovered that he has been dreaming everything that happened in the film and, believing that key to his problem is on the roof of the building, he strides toward it. The building, once again recognizable to any Madrileño, is the Torre Picasso, located in the AZCA commercial center along the Avenida de la Castellana, the city's tallest building, and symbol of economic vitality-and as we shall see abuses as well. The Torre Picasso is filmed in this sequence in such a way that it overflows the screen in much the same way that Amenábar shot the Torre de Madrid, which was Madrid's tallest structure for a long time, and the visual anchor of place for the sequences that begin this film.

In his interview with Carlos Heredero in Espejo de Miradas, Amenábar admits that his mentor, the producer and director José Luis Cuerda, threatened to break all of his lenses over $40 \mathrm{~mm}$ because Amenábar tended to abuse them. The subsequent sequence of $A$ Abre los ojos depends on Amenábar's selection of lenses for its visual citing of place. Antonio and César ascend the stairs that take them to the roof of the Torre Picasso. They are framed by the twin towers of the Puerta de Europa, previously known as the Torres KIO, filmed with a lens that draws this building much closer to the Torre Picasso than it is. The shots that follow are done with an entirely different lens but maintain the connection between César's personal dilemma and the urban by framing the shots in such a way that it is always evident the he is on top of one tall important building and that the other one is also always there. The built environment is inescapable, just as it is in the shots that begin the film.

Subsequent shots, as the film moves to its conclusion, take the towers completely out of the range as César discovers the truth about his dreams, talking with the representative of the Life Extension Corporation. The towers appear again in closer focus when Antonio descends the stairs to find out how $4,000,000$ Madrileños have suddenly disappeared. The representative of Life Extension explains to César the nature of his predicament and tells him that he can end his dream, be unfrozen, and live in the future instead of the virtual reality of his dream simply by committing virtual suicide and jumping off the Torre. César decides to do it. The representative asks César if he has any last requests. César looks upward and when he lowers his gaze the camera shoots his love, Sofía, with the Puerta de Europa over her left shoulder and in the right hand corner of the screen. We see the towers again, then as César approaches Sofía the camera draws back to show César embracing Sofía and 
his best friend, Pelayo, in the background. All of these last "dreams" are done with the Puerta de Europa in the frame.

César gets ready to jump. When he does so he leaps away from the towers, and back toward the center of the city where we can see the rest of the AZCA complex with the Nuevos Ministerios government complex-begun by the same architect who designed the plan for the extension of the Gran Vía that ends with the Plaza de España where the Torre de España is located-behind it.

César's urban nightmare is indeed one framed by key elements of the processes of the urbanization of capital and these obviously weigh heavily on the urbanized consciousness of Amenábar as expressed in this film. In spite of its sleek international look, which has attracted attention around the world and lured its young director into the sphere of influence of Hollywood, this film remains tied to place. The places represented in the film, aside from the portrayal of important representations of Madrid's built environment, are quite in line with a vision of consumerist urbanity. The space portrayed is all commodious private dwelling, public monuments, sleek private clinics, and watering holes. The city is traversed only in elegant vehicles, including a retro, pristine VW beetle convertible and a sleek Alfa Romeo. The state is reduced to its repressive elements-psychiatric hospitals and police stations-while César's fate remains in the hands of modern technology linked to multinational corporations like the Cryonic Firm Life Extension-which paradoxically has its freezing vats in Arizona! Nevertheless, the film evokes an image of the urban which forces us to see how we interact with our environment and what happens if we ignore it; a counter argument to the dream of consumerism that requires us to open our eyes to the built environment and its effect on those who live in the city. Amenábar can make César's urban nightmare go away by committing suicide for the second time and assuring that he live in the future, but the contextualization of his life suggests the real urban nightmare and its effects do not go away so easily. We only have to open our eyes to how Amenábar presents the relationship between the personal and the built environment.

El día de la bestia, released two years earlier, also examines the dichotomy of monuments to modernity along the Gran Vía and the Torres KIO (now Puerta de Europa). The most important moments in the film's narrative advancement are the ones in which the action takes place in buildings wholly familiar to any Madrileño and to most urban Spaniards: The Edificio Capitol and the Puerta de Europa. The construction of these landmarks was tied to efforts to link the construction of Madrid with ideas of what a metropolis should look like, which circulated through the debates about modernity during the period in which the buildings were constructed. The monuments that Alex de la Iglesia employs are emblematic of Madrid's hopes for itself as a (post)modern metropolis. At the same time, nevertheless, the monumental public space is contrasted with 
private spaces that underscore the unsolved urban ills still visible in Madrid in the 1990s.

At the end of the film, after a series of disastrous attempts to unravel the crucial enigma of where Satan will appear, Angel is physically and emotionally drained. It is now Cavan, himself the worse for wear after his fall from the Schweppes sign, who discovers where Satan is to appear. Standing on an overpass, Cavan explains exactly what the "casa del diabolo" (as he calls it in his broken Spanish) must look like. He then invites Angel, who is facing him, to turn around and view it. De la Iglesia first films a full frame close up of Angel's perplexed face, followed by a reverse angle of the cause of his consternation: the enormous Puerta de Europa whose twin inclined towers rise out of the redesigned Plaza de Castilla. The next shot is from the position occupied by Cavan and José María. When we see Angel in the center, flanked by the enormous inclining twin towers, he begins to raise his arms as a kind of instinctive imitation of a cross but stops short and inadvertently allows his arms to make the same form as the building. The camera shifts back to a reverse angle filming the three protagonists against the backdrop of the underpass that has eliminated the necessity of traffic flowing around the Plaza de Castilla. The subsequent shot follows Angel as he moves forward, his arms still inadvertently between the form of a cross and that of the inclined towers of the building. As he does so, the camera takes up a long shot of the Plaza and we see in the center the monument to Calvo Sotelo, which now stands between the twin towers. The sequence of shots that de la Iglesia employs to film the exterior of the Capitol building (close up, medium, then long enabling shots) is very similar to the way he films Madrid's twin towers. The long shots situate the two monuments in their place and symbolically link them to the Gran Vía and the Castellana whose redesign they symbolize.

If any design project could qualify as the "casa del diabolo," as Cavan calls them in his broken Spanish, the Puerta de Europa, once Torres KIO, could certainly be a candidate. Not because the inclined shape of its towers could be construed as Satan's attempt to have his house imitate the shape of the house of God, but because they represent all that went wrong in the history of urbanization in Spain under socialism and the redesign of Madrid in the hands of the governments that succeeded the PSOE in the 1990s. It is here that the dialectic between Spanish and international space and place finds true symbolic representation. It is also here that we can reread the narrative of redesigning Spain in relationship to the political and market forces of flexible accumulation and consumption. The significance of the Torres $\mathrm{KIO}$, as the Puerta de Europa was still known at the time de la Iglesia shot his film, was not lost on the director.

Were it only a matter of the design of a single ugly building, perhaps the Puerta de Europa project would not have had such an impact on the urbanization of consciousness. What makes this particular project so important is that it evokes 
so many of the processes involved in the urbanization of capital and the urbanization of consciousness under flexible accumulation. Perhaps the geometric similarity between the shape of the building and the cloven hoof of satanism is only coincidental. At any rate, it made it very easy for de la Iglesia to make one of Madrid's most controversial design projects in recent years into the site of the "casa del diabolo." In El día de la bestia, the relationship between capital and urban consciousness de la Iglesia presents serves as an antidote to the hegemonic version of this underlying relationship that in the discourse of postmodern urban design.

De la Iglesia's film is truly radical. It articulates the processes that contribute to the urbanization of consciousness at a particularly important juncture in Spain's history. It forms a focus of resistance to the kind of political thinking that attributes all responsibility for Spain's ills to the policies of the central government in Madrid and the corruption that ensued from those policies, while clearly focusing on the local issues and the need for local solutions to issues of place.

What is significant is that Amenábar's film, by capturing key elements of Madrid's built environment, visually links two buildings that were actually linked through processes of economic speculation. The offices of Los Alberto were located in the Torre Picasso, about a mile up the Castellana from where KIO originally had its offices. It was there that the deals to speculate with the land in the Plaza de Castilla and have Construcciones y Contratas build the towers were originally hatched. Interestingly, the plans for the remodeling of the Castellana, going from the Plaza de Castilla to Fuencarral, meant to complete Madrid's march to the north, were done in one of the towers of the Puerta de Europa, where Direcciones Urbanísticas Chamartín has its design offices.

De la Iglesia's film stands as an antidote to the processes of urbanization that have converted Madrid into the "casa del diabolo." A case could be made that Amenábar's film does the same if we read the title as the necessity of opening one's eyes to place. The significant way in which Amenábar situates monuments in relation to urbanization and quotes El día de la bestia, albeit obliquely, appears to me to militate against the slick vision of urban space the film portrays. Amenábar lays bare the internal tensions between space and place. This is vividly seen in the fact that César's nightmare begins on the Gran Vía and ends on the Torre Picasso. He literally cannot disassociate himself from the dilemmas of urbanization. By situating the protagonist on the Torre Picasso, Amenábar demonstrates this inability since there is no place César can jump that will dissociate him from the built environment that issues from Madrid's urbanized capital. By "placing" his protagonist here the director clearly demonstrates that you cannot escape place.

Fernando León de Aranoa's Barrio is about those who are left behind in capitalism's uneven development in space and time, the victims of the periodic 
bouts of creative destruction that are the essence of capital. As León de Aranoa himself asserts, the images of his film form a synthetic space out of the real places of the run-down neighborhoods of Madrid's southern tier.

Esta es una película sobre la periferia de las cosas, sobre aquello que las rodea, que las sostiene. Sobre la periferia de las grandes ciudades...

Transcurre en un barrio cualquiera, a los que no llega ni el metro ni el dinero. Un barrio gris, cuatelero, hermético, un barrio que en la realidad no es ninguno y quiere ser todos. [10]

The city that León de Aranoa presents stands in stark contrast to the city seen in sleek thrillers like Tesis, Abre los ojos, and the spate of youth films that filled out the urban imaginary vision of Madrid, from Historias del Kronen and Mensaka to Marta y alrededores and Las razones de mis amigos. In some ways, its vision of youth stands in vivid contrast to those in these other films and even to the hectic pace of life in El día de la bestia. In this way it is closer to Saura's ground breaking Deprisa Deprisa than to its companion films of the 1990s. Pursuing this approach leads León de Aranoa's work in directions far removed from the theater of imaginary family filmed in his first feature, Familia, and roots $\underline{B a r r i o}$ in the drama of real social relationships.

Barrio chronicles the lives of three fifteen year old boys who live in one of the satellite cites on Madrid's southern edge. There, chabolas gave way to cheap housing and were supplanted in time by higher rise ciudades dormitorios, which are crisscrossed by various iterations of beltways and train tracks that themselves fracture the landscape. It is August, the boys and their families are suffering through hard times and they have no place to go. All they have is their dreams of spending vacation time someplace else-perhaps a beach in a resort in Spain or elsewhere-fueled by their incomplete vision of the world outside of their own barrio, lavish publicity campaigns, and media reports. They inexorably get bound in circuits of frustration that eventually lead to tragedy.

León de Aranoa plots this visually through a brilliant portrayal of the relationships of space, time, and money that mediate the lives of Rai, Manu, and Javi, the young protagonists. The "barrio de toda la vida" where they live, a series of aging older buildings, is brought into sharper focus as the director films them against the backdrop of ever-taller buildings that supplant them as the city expands outward. This opens our eyes to the layers of poor urban planning that fixes the spatial fate of these characters.

Movement through space is a key issue here. David Harvey has pointed out how cultural works spatialize class relationships, for example, the fluidity with which characters traverse space. [11] Dickens stands in sharp contrast to the space in novels by Gissing where capital is seen as imposing much stricter limits on freedom of movement. This is certainly applicable to Barrio. Manu seeks employment as a pizza delivery boy in order to earn some money, but 
since he has no moto he has to deliver the pizzas by bus and by foot, demonstrating the tortuously slow rate of public transportation in the barrio for all those who do not have an automobile and the added fractured nature of the urban landscape which makes it even more difficult to navigate.

The most vivid symbol of being stuck in space is the Jet Ski that Rai wins in a contest by sending in tops of yogurt containers that he has had to steal from a local supermarket since his mother will not buy them because they are too expensive. He wants the vacation offered as first prize, one that would allow him to escape his spatial confinement. He wins a Jet Ski that sits uselessly in front of his family's apartment building. The useless prize indicates the boys' fixedness in space in a society whose winners are those with the ability to conquer it. Even when they win, they loose.

The boys' private hideaway is the clearest visual image of their fate. Situated in a ditch near a culvert, amid piles of refuse, beside a highway, the boys dream on car seats from older vehicles that have been tossed aside. The shots of the three friends sitting on an overpass to the $M-40$ watching cars zoom by, or the ones of them on the metro going toward the center of the city reinforce this. In the latter they are always shot exactly the same way. These repetitive images give the impression that they are going no place. The boys' fixedness stands in sharp contrast to the fluidity with which space is traversed in other less critical movies that thematize Madrid, as well as in the "road pictures" that have become an interesting sub-genre in recent Spanish film. In fact, Barrio's tragic ending is put in motion by Rai's desire to steal a car so that he can take Javi's older sister out on a date. Symbolically, the reactions of Javi to Rai's death are filmed through the window of a metro car.

Movement to and from the big city that looms in the distance is also indicative of their fixedness in space. The city center is an alien place where they are not really welcome, and where they are frustrated. The sleek, hospitable city of consumption is not available to them. Even when they have money to buy things they are shunned as outsiders. Various scenes in the movie indicate this voyeuristic relationship to the metropolis.

The social relationships in the film indicate the effects of uneven capital development in space, time, and place. All of the families are suffering through difficult times that put a tremendous strain on family relationships. [12] These struggles are brought into sharper focus by their dreams of wishing things were better and by the constant drone of Matías Prats, hijo, on the ever-present television talking about the vacations others are able to afford, and the everimproving economic situation that is nowhere evident in their lives. In fact, the only community on which the boys can rely is the informal community of friendship. This is vividly brought home by Javi's reaction to Rai's death. Public institutions are themselves only manifest through forms of social repression 
such as police and private security guards, and through a public transportation system that seems inadequate to the space it services.

Abre los ojos is a fitting image for films that to varying degrees comment on capital's effect on urban life. If we open our eyes we can perceive the ways in which these films afford varied responses that contest hegemonic capital's control of the urban process.

The real spaces and places of El día de la bestia contest this situation by equating the transformation of the city it works with a pact with the devil. It is interesting in this note that Alex de la Iglesia's most recent film, the critically acclaimed La comunidad (2000) returns to the urban issues that were not of prime concern in the two films following Día (Perdita Durango and Muertos de risa). When treating the ways in which capital perverts our consciousness he finds his most authentic and powerful voice. The spaces and places of $\underline{\text { Abre los }}$ ojos occupy a middle ground suggesting a way of seeing that makes the hidden hand of capital visible in the construction of the urban while at the same time having its other foot deeply in the land of the commodified, ready-made plot agendas that locate it in the land of the Hollywood wanabees. Barrio creates a synthetic space out of a variety of real places. Its poignant vision of the losers in the world of accumulation lays bare the problems not solved by urban reform and underscores what was lost when urban governments in Madrid abandoned issues of social justice.

It is, of course, not only Abre los ojos that walks the tightrope between critical responses to the urban experience film's location, smack in the middle of processes of commodification themselves. Every effort to contest capital needs capital to wage that struggle. Money may be the root of all evil, but in the current community of money having it can do some good. All of these films have been successful and their directors have gained a great degree of notoriety. They have all been actively marketed-several have their own web sites-and best-selling soundtracks of all of them have appeared.

At the same time, we must be cognizant that even the most contestatory forms of cultural expression can, as Stephen Duncomb points out in his magnificent book on the culture of zines, be swept away by capital's increasing capacity to commodify everything in newer and newer iterations of what Thomas Frank has called the "conquest of cool." In the last analysis all we can do is to open our eyes to the process and attempt to be accurate in our attempts to denounce it and in this way take the first steps to clarify the issue of whose city it really is and build the ground work for a communal response. In so doing, we should always be cognizant of Lefebvre's crucial observation that no revolution can succeed that does not fundamentally alter space, especially urban space.

I end, as I began, with a reference to the city. This seems a fitting way to bring into sharper focus the need to fold into discussions of issues of national and 
post-national identity the fundamentally urban nature of capital and of space, all too absent from our discussions of the transformations overtaking Spain and its cultures. I hope that I have suggested this type of reading.

\section{Notes}

1 The material in this essay is drawn from a book manuscript on the relationship between culture, capital, and the processes of urbanization as they have played out recently in Madrid.

2 The nature of this study does not permit a full treatment of the relationships between urban space, or space in general, and the ideas on identity as they have been used to articulate a variety of approaches to identity in Spain. Suffice it to say that it is significant that two of the most prominent approaches to the issue are Juaristi's El bucle melancólico and Rubert de Ventos's Nacionalismos. El laberinto de la identidad, and they employ spatial metaphors as a way of gaining access into the issue.

3 There is a growing body of specialized literature on the planning process in Madrid. Trapero offers a useful summary of modern urban planning in Spain. De Terán offers the most comprehensive assessment of urban planning in Madrid. La comunidad de Madrid provides a wealth of information about the formation and organization of Madrid's autonomous community.

4 See Harvey 1989, 256-278; Harvey 1990, 66-98; Harvey 2000, 133-165; and Ghirardo 7-42.

5 The Mesa Redonda, "El urbanismo español en la última década," published in the first issue of the influential journal Urbanismo, provides an important view on the relationships between capital, political change, and the way planners and architects need to conduct business. The responses of the participantsmany of whom had been busy in the previous decade developing new urban plans for Spain's major cities and regiones autonómicas, are endemic of the state of flux that characterized Spain's urban regions. In the first place, the political nature of planning had changed. Plans were no longer issued from a central government ministry. They were now in the hands of planning departments of seventeen, recently created regiones autonómicas and a myriad of municipalities-many of which are the result of the break up of the great urban agglomerations of the "áreas metropolitanas" of Madrid, Barcelona, and other large cities. Moreover, planning was now more directly related to the political process. Elected government meant planning had to reflect the needs of the governed. De Terán also provides insightful comments on this process. See 323-385. 
6 Particularly useful to establishing the relationship between space and cinema are the articles by Gold and Ward and Easthope. Dear, 176-198, provides a useful review of the myriad of studies that deal with this subject.

7 More information about Amenábar and recent Spanish cinema can be found in Heredero 1997 and 1999 and Sempere.

8 Heredero 1997 and 1999 provide useful information about León de Aranoa. Company and Marzal also provide some useful insights about Barrio. Barrio, the published screenplay, is also very helpful.

9 Amenábar Interview in Plató Interactivo. See also Sempere, 89-92. Gorostiza offers an encyclopedic treatment of the presentation of architecture in cinema.

10 León de Aranoa, "Periferia," 275.

11 Harvey 1989, 178.

12 Company and Marzal provide corroboration on this point and suggest interesting connections between Barrio and the work of Rafael Azcona.

\section{Works Cited}

Amenábar, Alejandro (Director). Abre los ojos (film). Las producciones del Escorpión, 1997.

---. " Interview." Plató Interactivo.

[http://www.Cine.lavanguardia.es/cast/plato/entrevis/Amenabar/Amenabar.htm]. ---. "Interview with Carlos Heredero." In Espejo de miradas: Entrevistas con nuevos directores del cine español de los años noventa. Alcalá de Henares:

Festival de cine de Alcalá de Henares, 1997. 83-114.

Clarke, David B. (Ed.). The Cinematic City. London: Routledge, 1997.

Company, Juan Miguel and Marzal, José Javier. La mirada cautiva. Formas de ver en el cine contemporáneo. Valencia: Generalitat Valenciana, 1999.

Compitello, Malcolm Alan. "From Planning to Design: The Culture of Flexible Accumulation in Post-Cambio. Madrid." Arizona Journal of Hispanic Cultural Studies, 3 (1999): 199-219.

De la Iglesia, Alex (Director) El día de la bestia (film). Sogetel, 1995.

De Terán, Fernando. Historia del Urbanismo en España. III. Siglos XIX y XX. Madrid: Cátedra, 1999. 
Dear, Michael J. Postmodern Urbanism. London: Blackwell, 2000.

Duncombe, Stephen. Notes From Underground. Zines and the Politics of Alternative Culture. New York: Verso, 1997.

Easthope, Anthony. "Cinécities in the Sixties." In The Cinematic City. Ed. David B. Clarke. London: Routledge, 1997. 129-139

Ghirardo, Diane. Architecture After Modernism. New York: Thames and Hudson, 1996.

Gold, John R. and Stephen V. Ward. "Of Plans and Planners: Documentary Film and the Challenge of the Urban Future, 1935-1952." In The Cinematic City. Ed. David B. Clarke. London: Routledge, 1997. 59-82.

Gorostiza, Jorge. La imagen supuesta. Arquitectos en el cine. Barcelona: Fundación Caja de Arquitectos, 1997.

Harvey, David. The Condition of Postmodernity. London: Blackwell, 1990. ---. Justice, Nature and the Geography of Difference. London: Blackwell, 1996.

---. Spaces of Hope. Berkeley: California UP, 2000.

---. The Urban Experience. Baltimore: Johns Hopkins UP, 1989.

Heredero, Carlos. 20 nuevos directores del cine español. Madrid: Alianza, 1999.

---. Espejo de miradas: Entrevistas con nuevos directores del cine español de los años noventa. Alcalá de Henares: Festival de cine de Alcalá de Henares, 1997.

Juaristi, Jon. El bucle melancólico. Historias de nacionalistas vascos. Madrid: Espasa Calpe, 1999.

Kinder, Marsha. "Refiguring Socialist Spain: An Introduction." In Refiguring Spain. Cinema/Media/Representation. Durham: Duke UP, 1997. 1-32.

León de Aranoa, Fernando (Director). Barrio (film). Elías Querejétera, 1998. ---. Barrio. Madrid: Academia de las artes y las ciencias cinematográficas, 2000.

---. "Periferia". In Barrio. 275-276.

López Nieto, Lourdes (Ed.). La Comunidad de Madrid. Balance de quince años de experiencia autonómica. Madrid: Istmo, 1999. 
Martínez Bouza, Rogelio. "La sensibilidad purista de Adolfo Domínguez." AIC 29 (1986): 44-51.

Mesa redonda: "El urbanismo español en la última década." Urbanismo 1 (1987): 8-24.

Moya González, Luis (Ed.) La práctica del planeamiento urbanístico. Madrid: Editorial Síntesis, 1998.

Philo, Kris and Kearns, Gerry. "Culture, History, Capital: A Critical Introduction to Selling Places." In Selling Places. The City as Cultural Capital Past and Present. Ed Gerry Kearns and Kris Philo. Oxford: Pergamon, 1993. 1-32.

Recuperar Madrid. Madrid: Ayuntamiento de Madrid, 1982.

Rubert de Ventós, Xavier. Nacionalismos. El laberinto de la identidad. Madrid: Espasa Calpe, 1999.

Sempere, Antonio. Alejandro Amenábar. Madrid: Nuer Ediciones, 2000.

Trapero, Juan Jesús. "La práctica del planeamiento urbanístico en España." In La práctica del planeamiento urbanístico. Ed. Luis Moya González. 19-38.

Zukin, Sharon. Loft Living. New Brunswick: Rutgers UP, 1989. 